\title{
NANO KITOSAN EKSTRAK TONGKOL JAGUNG MANADO KUNING (Zea Mays L.) DAN AKTIVITAS ANTIOKSIDANNYA
}

\author{
Julista Alfa Kabalmay $^{{ }^{*}}$, Edi Suryanto ${ }^{1}$ dan Max R.J. Runtuwene ${ }^{1}$ \\ ${ }^{1}$ Jurusan Kimia Fakultas Matematika dan Ilmu Pengetahuan Alam Universitas Sam Ratulangi, \\ Jl. Kampus Unsrat, Kleak, Manado 95115 Sulawesi Utara
}

\begin{abstract}
ABSTRAK
Tujuan dari penelitian ini untuk mengetahui potensi antioksidan dari nanopartikel kitosan ekstrak tongkol jagung Manado kuning. Penelitian ini terdiri dari 2 tahap yaitu ekstraksi dan pembuatan nanopartikel kitosan. Parameter yang digunakan adalah total senyawa fenolik dan kemampuan mereduksi, ukuran partikel, indeks polidispersitas, dan morfologi permukaan nanopartikel kitosan ekstrak tongkol jagung Manado kuning. Pembuatan nanopartikel kitosan menggunakan metode gelasi ionik. Hasil penelitian menunjunkkan partikel serbuk tongkol jagung $75 \mu \mathrm{m}$ memiliki rendemen dan kandungan total fenolik yang lebih tinggi dibanding ukuran $150 \mu \mathrm{m}$. Formula F1 nanopartikel kitosan ekstrak tongkol jagung memiliki ukuran partikel yang lebih kecil $(318,7 \mathrm{~nm})$ daripada F2 $(333,8 \mathrm{~nm})$, dan F3 $(339,9 \mathrm{~nm})$. Hasil pengamatan morfologi permukaan nanopartikel kitosan adalah berbentuk seperti gumpalan yang masih berukuran mikrometer dan bentuk bulat tidak sempurna. Hasil pengujian aktivitas antioksidan bahwa formulasi F1 memiliki aktivitas yang terbaik dibandingkan dengan F0, F2 dan F3.
\end{abstract}

Kata kunci: Kitosan, jagung Manado kuning, nanopartikel

\section{ABSTRACT}

The objective of this study was to determine the antioxidant potential of chitosan nanoparticles from corncob extracts of Manado yellow corn. The study was consist of two stages: extraction and synthesis of chitosan nanoparticles. The parameters evaluated were total phenolic content (TPC), reducing power, particle size, index of polydispersity, and surface morphology of chitosan nanoparticles from Manado yellow corncob extract. Synthesis of chitosan nanoparticles was carried out by using ionic gelation method. The result showed that corncob powder with particle size $75 \mu \mathrm{m}$ had higher recovery yield and higher total phenolic content $(150 \mu \mathrm{m})$ than $150 \mu \mathrm{m}$. Formula F1 chitosan nanoparticles extract of corncob had smaller particle size $(318.7 \mathrm{~nm})$ compared to F2 $(333.8 \mathrm{~nm})$ and F3 $(339.9 \mathrm{~nm})$. Surface morphology observation revealed that the shape of chitosan nanoparticles were like lumps with imperfect round shape within micrometer-size. Antioxidant activity assay showed that the F1 had the highest antioxidant activity compared to F0, F2 and F3.

Keywords: Chitosan, Manado yellow corn, nanoparticle

\section{PENDAHULUAN}

Jagung adalah salah satu produk pertanian yang banyak dihasilkan di Negara Indonesia. Pada kegiatan pertanian jagung akan menghasilkan limbah tongkol jagung 20,87\% dan $19,13 \%$ yang terdiri dari batang, daun, dan kelobot. Menurut data Kementerian Pertanian (2018), produksi jagung rata-rata diperlukan sebanyak 30 juta ton per tahun. Produksi jagung tersebut akan menghasilkan limbah tongkol jagung sekitar 25 juta ton per tahun. Tongkol jagung merupakan salah satu limbah lignoselulosik yang banyak tersedia di Indonesia. Limbah lignoselulosik adalah limbah pertanian yang mengandung selulosa, hemiselulosa, dan lignin (Supranto \& Rasyid, 2002). Penelitian lain melaporkan bahwa ekstrak dan fraksi tongkol jagung menunjukkan aktivitas antifotooksidan dan fotoproteksi secara in vitro menggunakan asam linoleat (Suryanto dkk., 2013; Suryanto dkk., 2018). Akan tetapi, kesulitan yang terjadi dalam pemanfaatan tongkol jagung adalah komponen serat pangan dan antioksidan memiliki kelarutan dalam air sangat rendah, laju kelarutan lambat, bioavailabilitas rendah dan teksturnya kasar.

Mikronisasi merupakan teknik yang ekonomis dan efektif untuk membuat partikel sangat halus, yang ukuran partikelnya berkisar dari $1 \mathrm{~nm}$ hingga $100 \mu \mathrm{m}$ (Zhao dkk., 2009). Pengurangan ukuran partikel tepung antioksidan serat pangan dari tongkol jagung mengubah struktur dan karakteristik permukaannya, yang pada gilirannya mengubah sifat fungsional dari tepung antioksidan serat pangan (Wang dkk., 2012). Oleh karena itu, teknologi nano banyak 
dikembangkan dan menjadi tren dalam pengembangan dan peningkatan kualitas produk pangan fungsional. Nano-teknologi sangat berkembang karena memiliki banyak keunggulan seperti ukuran partikel yang lebih kecil memiliki sifat yang khas dibandingkan dengan ukuran partikel yang lebih besar dan fleksibel dikombinasikan dengan teknologi lain sehingga dapat dikembangkan untuk berbagai keperluan. Teknologi nano banyak dikembangkan sebagai penghantar zat aktif dalam suatu produk pangan maupun obat untuk mengatur laju pelepasan senyawa zat aktif, meningkatkan kelarutan, dan meningkatkan penyerapan dalam tubuh. (Ningsih dkk., 2017).

Berdasarkan penelitian di atas senyawa dari ekstrak tongkol jagung Manado kuning yang berpotensi sebagai antioksidan dapat dibuat dalam bentuk nanopartikel kitosan ekstrak tongkol jagung. Penggunaan teknologi nano ini diharapkan dapat berfungsi sebagai pengantar dalam meningkatkan dispersi senyawa bioaktif dalam produk makanan dan meningkatkan kestabilan komponen itu sendiri ketika bercampur dengan komponen-komponen lainnya. Oleh karena itu, peneliti tertarik untuk melakukan penelitian tentang aktivitas antioksidan dan penghambat pembentukan AGEs (Advanced Glycation End-Products) dari nanopartikel kitosan ekstrak tongkol jagung Manado kuning.

\section{BAHAN DAN METODE}

Bahan yang digunakan dalam penelitian yaitu tongkol jagung Manado kuning yang diperoleh dari Ratahan, Kecamatan Minahasa Tenggara Sulawesi Utara. Bahan yang digunakan yaitu, etanol $80 \%$, natrium karbonat $2 \%$, reagen Folin-Ciocelteu 50\%, larutan buffer fosfat, kalium ferisianat $1 \%$, asam trikloroasetat, $\mathrm{FeCl}_{3} 0,1 \%$, aquades, kitosan (100 KDa-150 KDa 97,88 \% ukuran partikel 200-300 mesh), tween 80, STTP (Sodium tripolifosfat, Chimultiguna), Alat yang digunakan yaitu alatalat gelas, vortex, kertas saring, aluminium foil, timbangan analitik, rotary evaporator, blender, milling (Fomac tipe FCT-Z200 tegangan $220 \mathrm{~V}$ daya $1 \mathrm{KW}$ frekuensi $50-60 \mathrm{~Hz}$ kecepatan putar $28.000 \mathrm{rpm}$ ), 150 dan $75 \mu \mathrm{m}$, rak tabung, micro pipet, gelas ukur, oven, petridis, desikator, sudip, botol vial, sentrifugasi, Spektrofotometer Uv-Vis (Shimadzu) PSA (Horiba), SEM (Phenom ProX) dan Sonikator (Krisbow $40 \mathrm{KHz}$ ).

\section{Perparasi sampel}

Sampel tongkol jagung bersihkan dan dicuci dengan air untuk memisahkan bagian yang terapung. Setelah itu $1000 \mathrm{~g}$ tongkol jagung diblender dengan aquades selama 2 menit dan disaring menggunakan kain blacu, Ampas tongkol jagung kemudian dipanaskan dengan aquades $1000 \mathrm{~mL}$ selama 1 jam sambil diaduk. Kemudian disaring untuk memisahkan ampas dengan filtrat, ampas selanjutnya dikeringkan di dalam oven pada suhu $50-60{ }^{\circ} \mathrm{C}$ selama 48 jam (kadar airnya $<10 \%$ ). Ampas tongkol jagung yang sudah kering digiling menggunakan alat miling Fomac tipe FCT-Z200 selama 2 menit. Hasil miling dalam bentuk serbuk, kemudian di ayak menggunakan ayakan 150 dan $75 \mu \mathrm{m}$.

\section{Ekstraksi tongkol jagung}

Serbuk tongkol jagung Manado kuning yang berukuran 150 dan $75 \mu \mathrm{m}$ ditimbang sebanyak $5 \mathrm{~g}$ dilarutkan dengan $50 \mathrm{~mL}$ etanol 80 $\%$ kemudian disonikasi dengan frekuensi 40.000 Hz selama 30 menit, setelah disonikasi sampel di saring, dan dipekatkan menggunakan rotari evaporator, Ekstrak yang diperoleh ditimbang dan disimpan pada suhu $0{ }^{\circ} \mathrm{C}$ sebelum dianalisis kandungan total fenolik dan aktivitas antioksidan.

\section{Pembuatan nanopartikel kitosan ekstrak tongkol jagung}

Pembuatan nanopartikel kitosan ekstrak tongkol jagung menggunakan ekstrak yang terbaik dari ukuran partikel serbuk. Selanjutnya pembuatan nanopartikel kitosan ekstrak ditentukan menggunakan metode Madderla \& Sundari (2018). Sebanyak $2 \mathrm{~mL}$ larutan ekstrak tongkol jagung $(1 \mathrm{mg} / \mathrm{mL})$ ditambahkan dengan $40 \mathrm{~mL}$ kitosan dengan berbagai konsentrasi $(0,1$; 0,2 dan $0,3 \%$ ) dan divorteks selama 5 menit setelah itu dicampurkan dengan $0,3 \mathrm{~mL}$ Tween 80 dan divorteks selama 5 menit. Selanjutnya ditambahkan perlahan-lahan $10 \mathrm{~mL}$ STTP $0,1 \%$ dan diaduk menggunakan pengaduk magnet selama 10 menit. Nanopartikel kitosan yang telah terbentuk kemudian disimpan pada suhu $5{ }^{\circ} \mathrm{C}$ sebelum dikarakterisasi, dianalisis kandungan total fenol dan aktivitas antioksidannya.

\section{Karakterisasi nanopartikel kitosan}

Nanopartikel kitosan yang telah disintesis kemudian dikarakterisasi menggunakan Particles Sized Analyzer (PSA) untuk mengetahui ukuran partikel, dan untuk pengamatan morfologi permukaan nanopartikel 
kitosan dilakukan menggunakan Scanning Electron Microscopy (SEM).

\section{Penentuan kandungan total fenolik}

Kandungan total fenolik ditentukan menggunakan metode Jeong dkk. (2004). Sebanyak $0,1 \quad \mathrm{~mL}$ sampel $1000 \mu \mathrm{g} / \mathrm{mL}$ dimasukkan ke dalam tabung reaksi, lalu ditambahkan 0,1 $\mathrm{mL}$ reagen Folin Ciocalteu 50\% dalam tabung reaksi dan kemudian campuran divortex selama 3 menit. Setelah interval waktu 3 menit, ditambahkan $2 \mathrm{~mL}$ larutan $\mathrm{Na}_{2} \mathrm{CO}_{3} 2 \%$, kemudian campuran diinkubasi dalam ruang gelap selama 30 menit. Selanjutnya dibaca dibaca absorbansinya pada $\lambda 750 \mathrm{~nm}$ dengan menggunakan spektrofotometer UV-Vis.

\section{Penentuan daya reduksi}

Kemampuan mereduksi sampel ditentukan menurut Yen dan Chen (1995). Sampel (50-1000 ppm) dilarutkan dalam $1 \mathrm{~mL}$ aquades selanjutnya dicampur dengan buffer fosfat $(1 \mathrm{~mL}, 0,2 \mathrm{M}, \mathrm{pH} 6,6)$ dan $1 \mathrm{~mL}$ kalium ferisianat $1 \%$, campuran diinkubasi pada $50^{\circ} \mathrm{C}$ selama 20 menit. Setelah selesai diinkubasi campuran ditambahkan $1 \mathrm{~mL}$ asam trikloroasetat dan divortex selama 5 menit, selanjutnya disentrifusi pada $3000 \mathrm{rpm}$ selama 10 menit. Sebanyak $1 \mathrm{~mL}$ lapisan atas dari larutan tersebut ditambah dengan $1 \mathrm{~mL}$ aquades dan $0,5 \mathrm{~mL}$ besi (III) klorida $0,1 \%$. Absorbansi diukur pada $\lambda 700 \mathrm{~nm}$ dengan spektrofotometer. Meningkatnya absorbansi dari campuran tersebut berarti menunjukkan bertambahnya kemampuan mereduksi.

\section{HASIL DAN PEMBAHASAN}

\section{Ektraksi}

Penelitian ini menggunakan ekstraksi dengan sonikasi. Sampel tongkol jagung Manado kuning dengan ukuran partikel 150 dan $75 \mu \mathrm{m}$ disonikasi selama 30 menit menggunakan pelarut etanol $80 \%$ dan menghasilkan rendemen (\%) ekstrak sebanyak $0,248 \%$ dengan kandungan total fenolik $91,35 \mu \mathrm{g} / \mathrm{mL}$ untuk ukuran partikel 150 dan 0,5\% dengan kandungan fenolik 126,35 $\mu \mathrm{g} / \mathrm{mL}$ dengan ukuran partikel $75 \mu \mathrm{m}$. Dari data tsebut partikel serbuk tongkol jagung yang berukuran $75 \mu \mathrm{m}$ memiliki rendemen dan total fenolik lebih tinggi dibandingkan dengan 150 $\mu \mathrm{m}$. Hal ini dikarenakan ukuran dari serbuk tongkol jagung $75 \mu \mathrm{m}$ lebih kecil dibandingkan $150 \mu \mathrm{m}$, dimana semakin kecil ukuran partikel maka luas permukaannya semakin besar.
Begitupun sebaliknya semakin rendah nilai rendemen yang didapatkan dari hasil ektraksi semakin rendah pula kandungan total fenoliknya. Selain itu penggunaan metode ekstraksi sonikasi, ekstraksi senyawa tongkol jagung dapat berlangsung lebih cepat karena dinding sel dari tongkol jagung dipecah oleh getaran ultrasonik sehingga pelarut dapat dengan mudah masuk ke rongga sel yang mengandung zat aktif serta menurunan ukuran partikel. Zat aktif yang terkandung didalam sel akan terekstrak keluar karena adanya perbedaan konsentrasi zat aktif yang ada didalam dan diluar sel. Beradasarkan hasil tersebut serbuk tongkol jagung ukuran 75 $\mu \mathrm{m}$ dipilih untuk dilanjutkan ketahap pembuatan nanopartikel kitosan selanjutnya dikarakterisasi kemudian diuji total fenolik, aktivitas antioksidan.

\section{Pembuatan nanopartikel kitosan ekstrak tongkol jagung \\ Pembuatan nanopartikel kitosan ekstrak} tongkol jagung ditentukan menggunakan metode Madderla dan Sundari (2018). Nanopartikel ekstrak tongkol jagung dibuat dengan menggunakan kitosan dengan konesntrasi 0,1 ; 0,2 dan $0,3 \%$, natrium tripolifosfat $0,1 \%$, dan tween 80 . Penambahan tween 80 berfungsi untuk menstabilkan dispersi partikel dalam larutan dengan cara mencegah timbulnya aglomerasi antarpartikel. Keberadaan surfaktan mengakibatkan partikel-partikel kitosan di dalam larutan akan terselimuti dan terstabilkan satu dengan yang lain sehingga proses pembentukan nanopartikel akan semakin efektif. Penambahan natrium tripolifosfat bertujuan untuk membentuk ikatan silang ionik antarmolekul kitosan.

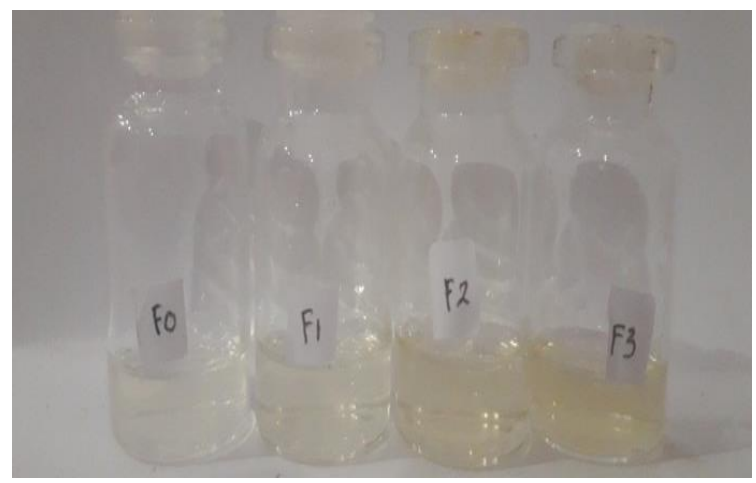

Gambar 4. Hasil pembuatan nanopartikel kitosan ekstrak tongkol jagung.

Keterangan: F0 (kitosan 0,1\% tanpa penambahan ekstrak) F1 (kitosan 0,1\% dengan penambahan ekstrak), F2 (kitosan 0,2\% dengan penambahan ekstrak) dan F3 (kitosan 0,3\% dengan penambahan ekstrak). 


\section{Karakteristik ukuran dan distribusi ukuran partikel nanopartikel kitosan ekstrak tongkol jagung}

Pengukuran diameter partikel pada penelitian ini menggunakan alat particle size analizer (PSA). Teknik tersebut dinilai lebih akurat jika dibandingkan dengan metode analisa gambar (mikrografi) dengan menggunakan SEM dan TEM terutama untuk sampel-sampel dalam ukuran nanometer dan submikron yang biasanya memiliki kecenderungan aglomerasi yang tinggi (Rawle, 2010). Hasil pengukuran menggunakan PSA dalam bentuk distribusi, sehingga hasil pengukuran dapat diasumsikan sudah menggambarkan keseluruhan kondisi sampel.

Tabel 2. Ukuran partikel dan indeks polidispersitas nanopartikel kitosan ekstrak tongkol jagung Manado

\begin{tabular}{cccc}
\hline Formula & $\begin{array}{c}\text { Ukuran } \\
\text { partikel } \\
\text { (nm) }\end{array}$ & $\begin{array}{c}\text { Indeks } \\
\text { polidispersitas }\end{array}$ & $\mathrm{pH}$ \\
\hline F0 & 304,6 & 0,590 & 3,6 \\
F1 & 318,7 & 0,459 & 3,3 \\
F2 & 333,8 & 0,427 & 3,3 \\
F3 & 339,9 & 0,537 & 3,4 \\
\hline
\end{tabular}

Distribusi ukuran partikel adalah karakteristik paling penting di dalam suatu sistem nanopartikel (Jahanshahi dkk., 2008). Untuk melihat suatu formula menjadi nanopartikel dapat diketahui dengan melihat distribusi ukuran partikel sampel tersebut. Hasil particle size analyzer (PSA) F0 dengan konsentrasi larutan kitosan $0,1 \%$ tanpa penambahan ekstrak menunjukkan distribusi ukuran partikel 304,6 nm. Hasil PSA F1 dengan konsentrasi larutan kitosan $0,1 \%$ menunjukkan distribusi ukuran partikel $318,7 \mathrm{~nm}$. Hasil PSA F2 dengan konsentrasi larutan kitosan 0,2 \% menunjukkan distribusi ukuran partikel 333,8 nm. Hasil PSA F3 dengan konsentrasi larutan kitosan $0,23 \%$ menunjukkan distribusi ukuran partikel 339,9 $\mathrm{nm}$. Dari ukuran partikel dari keempat formula menggambarkan bahwa ukuran partikel didapatkan seiring bertambahnya konsentrasi kitosan semakin besar ukuran parrtikel tersebut. Menurut Katas dkk. (2012) hal tersebut disebabkan oleh konsentrasi kitosan yang tinggi menyebabkan jumlah kitosan berlebih sehingga kitosan tersebut cenderung berikatan tidak beraturan satu dengan yang lain, kemudian bersambung silang dengan STTP yang membentuk satu partikel.
Penentuan nilai indeks polidispersitas digunakan untuk melihat persebaran ukuran partikel yang terjadi dalam nanopartikel yang telah diformulasi. Hasil dari ketiga formula berdasarkan pengukuran menggunakan metode Particle Size Analyzer memiliki Polidispersity Index (PDI) yang tinggi untuk tiap formula, yaitu secara berturut-turut untuk F0, F1, F2, dan F3 memiliki nilai sebesar $0.590 ; 0.459 ; 0.427$ dan 0.537. Data tersebut menunjukkan bahwa ketiga formula nanopartikel yang dihasilkan masih memiliki sifat polidispersi dan memiliki distribusi ukuran partikel yang luas terutama pada F2. Rentang indeks polidispersitas berada di antara 0 sampai dengan 1. Nilai indeks polidispersitas mendekati 0 menunjukkan dispersi yang homogen, sedangkan indeks polidispersitas dengan nilai lebih dari 0,5 menunjukkan heterogenitas yang tinggi (Avadi dkk., 2010).

\section{Kandungan total fenolik formulasi nanopartikel kitosan}

Metode dalam penentuan kandungan total fenolik yaitu Folin-Ciocalteu metode ini didasarkan pada kemampuan ekstrak untuk mereduksi reagen Folin-Ciocalteu (kuning) yang mengandung senyawa fosomolibdat dan asam fosfotungstat menghasilkan senyawa kompleks molybdenum-tungstat berwarna biru (JulkuenTiito, 1985). Asam galat digunakan sebagai standar karena asam galat diketahui memiliki aktivitas yang cukup tinggi terhadap reagen Folin-Ciocalteu dibandingkan dengan senyawa fenolik lainnya sehingga dapat di digunakan sebagai standar dalam penetapan kandungan total fenolik (Everette dkk., 2010). Hasil kandungan total fenolik dari nanopartikel kitosan ekstrak tongkol jagung Manado kuning dapat di lihat pada Table 3.

Tabel 3. Kandungan total fenolik dari nanopartikel kitosan ekstrak tongkol jagung

\begin{tabular}{cc}
\hline Sampel & $\begin{array}{c}\text { Kandungan total fenolik } \\
(\mu \mathrm{g} / \mathrm{mL})\end{array}$ \\
\hline F0 & $6,92 \pm 0,0^{\mathrm{a}}$ \\
F1 & $96,53 \pm 0,95^{\mathrm{b}}$ \\
F2 & $67,40 \pm 0,27^{\mathrm{c}}$ \\
F3 & $64,80 \pm 0,15^{\mathrm{c}}$ \\
\hline
\end{tabular}

Berdasarkan Tabel 3 dapat diketahui bahwa total fenolik tertinggi terdapat pada F1, F2 dan F3 berturut-turut adalah sebesar 96,53; 66,$53 ; 67,40$ dan $64,80 \mu \mathrm{g} / \mathrm{mL}$. Hasil uji Statistik 
menenjukan bahwa pada masing-masing konsentrasi kitosan memiliki perbedan nyata terhadap kandungan total fenolik. Semakin kecil ukuran partikel semakin tinggi pula kandungan total fenolik.

\section{Kemampuan mereduksi nanopartikel ekstrak tongkol jagung \\ Pengujian antioksidan dengan}

menggunakan metode daya reduksi dilakukan untuk mengetahui kemampuan mereduksi dari nanopartikel ekstrak tongkol jagung dengan konsentrasi kitosan yakni $0,1 \% ; 0,2 \%$ dan $0,3 \%$ ditunjukan pada Tabel 4.

Tabel 4. Kemampuan mereduksi nanopartikel ekstrak tongkol jagung Manado kuning

\begin{tabular}{cc}
\hline Sampel & $\begin{array}{c}\text { Kemampuan mereduksi } \\
(\text { Abs, } 700 \mathrm{~nm})\end{array}$ \\
\hline F0 & $0,15 \pm 0,02^{\mathrm{a}}$ \\
F1 & $0,94 \pm 0,01^{\mathrm{b}}$ \\
F2 & $0,89 \pm 0,01^{\mathrm{c}}$ \\
F3 & $0,69 \pm 0,01^{\mathrm{d}}$ \\
\hline
\end{tabular}

Berdasarkan hasil kemampuan mereduksi dari nanopartikel ekstrak tongkol jagung manado kuning dengan konsentrasi $0.1 \%$ (F1), $0.2 \%$ (F2), $0.3 \%$ (F3) dan $0.1 \%$ (F0 tanpa ekstrak) diperoleh hasil secara berturut-turut adalah 0.15 (F0), 0.94 (F1), 0.89 (F2), 0.69 (F3). Hasil uji stastistik menunjukan bahwa daya reduksi yang dihasilkan oleh nanopartikel ektrak tongkol jagung Manado kuning pada masing-masing konsentrasi kitosan memiliki perbedan nyata terhadap kandungan total fenolik. Pada table 4 terlihat bahwa dengan semakin kecil konsentrasi kitosan maka semakin kuat pula kemampuan mereduksinya.

\section{KESIMPULAN}

Ekstraksi menggunakan metode sonikasi selama 30 menit menunjukan bahwa ukuran partikel serbuk tongkol jagung $75 \mu \mathrm{m}$ memiliki rendemen dan kandungan total fenolik yang terbaik daripada $150 \mu \mathrm{m}$. Formula F1 nanopartikel kitosan ekstrak tongkol jagung memiliki ukuran partikel yang lebih kecil $(318,7$ $\mathrm{nm})$ daripada F2 $(333,8 \mathrm{~nm})$, dan F3 $(339,9 \mathrm{~nm})$. Hasil pengujian aktivitas antiosidan menunjukan bahwa formulasi $\mathrm{F} 1$ memiliki aktivitas yang terbaik dibandingkan dengan F0, F2 dan F3.

\section{DAFTAR PUSTAKA}

Avadi, M.R., Sadeghi, A.M., Mohammadpour, N, Abedin, S.F. Dinarvand, R., RafieeTehrani, M. 2010. Preparation and characterization of insulin nanoparticles using chitosan and Arabic gum with ionic gelation method. International Scholarly Research Network. 6(1), 5863

Everette, J.D., Bryant, Q.M., Green, A.M., Abbey, Y.A., Wangila, G.W., Walker, R.B. 2010. Thorough study of reactivity of various compound classes toward the Folin-Ciocalteu reagent. Journal of Agricultural and Food Chemistry. 58(14), 8139-8144.

Jahanshahi, M., Sanati, M.H. \& Babaei, Z. 2008. Optimization of parameters for the fabrication of gelatin nanoparticles by the taguchi robust design method. Journal of Applied Statistics. 35(12), 1345-1353

Jeong, S.M., Kim, S.Y., Kim, D.R., Jo, S.C., Nam, K.C., Ahn, D.U., \& Lee, S.C. 2004. Effect of heat treatment on the antioxidant activity of extracts from citrus peels. Journal of Agricultural and Food Chemistry. 52(11), 3389-3393.

Julkenen-Titto, R. 1985. Phenolic Consctituents In Leaves Of Northem Willows: Methods For The Analysis of certain phenolic. Journal Agrivulture Food Chemistry. 33(2), 213-271.

Katas, H., Hussain, Z. \& Ling, T.J. 2012. Chitosan nanoparticles as a percutaneous drug delivery system for hydrocortisone. Journal of Nanomaterials. 2012, 1-11.

Kementrian Pertanian. 2018. Petunjuk Teknis Pelaksanaan Kegiatan Jagung Tahun 2018. Kementrian Pertanian, Jakarta.

Madderla, S. \& Sundari, T.P. 2018. Formulation \& evaluation of curcumin loaded chitosan tripolyphosphate nanoparticles. International Education and Research Journal. 4(12), 6-8.

Ningsih, N., Yasni, S., \& Yuliani, S. 2017. Sintesis nanopartikel ekstrak kulit manggis merah dan kajian sifat fungsional produk enkapsulasinya. Jurnal Teknologi dan Industri Pangan. 28(1), 27-35.

Rawle, A. 2010. Basic principles of particle size analysis-technical paper of Malvern 
Instuments. Worcesstershire. United Wang, T., Sun, X., \& Zhou, Z. 2012. Effects of Kingdom.

Suprapto, H.S \& Rasyid, M.S. 2002. Bertanam Jagung. Penebar Swadaya, Jakarta.

Suryanto, E., Momuat, L.I., Rotinsulu, H., \& Mewengkang, D.S. 2018. Antiphotooxidant and photoprotective activities of ethanol extract and solvent fractions from corn cob (Zea mays). Internatiomal of Journal and ChemTech. Research. 11(3), 25-37

Suryanto, E., Momuat, L.I., Yudistira, A., \& Wehantouw, F. 2013. The evaluation of singlet oxygen quenching and sunscreen activity of corncob. Indonesian Journal of Pharmacy. 24(3), 274-283. microfluidization process on physicochemical properties of wheat bran. Food Research International 48(2), 742-747.

Yen, G.C \& Chen, H.Y. 1995. Antioxidant activity of various tea extracts in relation to their antimutagenicity. Journal of Agricultural and Food Chemistry. 43(1), 27-32.

Zhao, X.Y., Ao, Q., \& Yang, L.W. 2009. Application of superfine pulverization technology in biomaterial industry. Journal of the Taiwan Institute of Chemical Engineers. 40(3), 337-343. 